FOLLOWING hard on the heels of long awaited decisions about British nuclear power and ail comes the not unexpected news that the Maplin project for a 'third' London airport is to be abandoned. The decision has been made in the light of a reappraisal of the project made since the British election earlier this year, and comes just after the pub. lication of the British Airports Authority (BAA) Annual Report 1973/74 (HMSO, £2).

In that report, the Chairman of the BAA, Nigel Foulkes, commented: "The financial year brought a series of events which reduced the BAA's profits, slowed down the growth rate of the air transport industry sharply, and put all long-term plans for the future development of our airports back into the melting pot". What has now emerged from that melting pot is evidence that no further main runways will be required to handle expected traffic at the four airports in the London area

\section{Maplin project abandoned}

(Heathrow, Gatwick, Stansted and Luton) before 1990. With the noise nuisance now likely to be lower than forecast by the Roskill Commission (thanks to the advent of quiet widebodied jets) there is no need for a new airport at least until that time.

Capacity at both the principal London airports would have to be increased whether or not the Maplin project went ahead, the Secretary of State for Trade, $\mathrm{Mr}$ Peter Shore, told the House of Commons on July 17. The growth envisaged is from a capacity to handle 20 million passengers a year to 38 million in the case of Heathrow, and from the present 6 million passengers a year to 16 million for Gatwick.

If air traffic expands so that even this capacity is insufficient to meet the demand, various possibilities will be open to the planners of the mid-1980s. Stansted, which has been referred to as the "expansion chamber" of the existing British airport system, must once again seem high on the list for future development, and although $\mathrm{Mr}$ Shore commented in the House that major diversion of traffic from the south-east to airports beyond Bournemouth, Birmingham and the East Midlands does not seem attractive at present, in the long term there is still a possibility of developing airports as far away as Prestwick and Edinburgh. With the higher speed rail links which would be possible by the 1990s, such a diversion might then have more appeal.

Whatever happens in the long term, in the present atmosphere of uncertainty about air traffic and with general economic stringency, many will, no doubt, echo the words of $\mathrm{Mr}$ Eric Moonman, Member of Parliament for Basildon: "To save $£ 650$ million is a good afternoon's work".
LORD ROTHSCHILD said in 1971, a year after the appointment of a Central Policy Review Staff (CPRS) or 'think tank', that its and his success could be measured in terms of its survival. It had then survived somewhat longer than the equally novel Department of Economic Affairs-a parallel he drew - and this was despite the unnecessarily disruptive rumpus caused by the blunt instrument of the White Paper on the reorganisation of government research funding. The think-tank's continuation has now been officially endorsed by the present Labour administration and so tacitly subsumed as a permanent piece of government machinery, but Lord Rothschild is opting out. His successor as head of the CPRS is Sir Kenneth Berrill, a Treasury economist and former Chairman of the University Grants Committee.

The virtue of the original think-tank (whatever its shortcomings) was that it was Lord Rothschild 'writ large'. The fifteen or so bright young men that formed its analytical staff were all of his personal choosing. He was not, nor ever could be, a conditioned civil servant. His independent means removed him from the servitude of security in presenting his opinionsthough he has questioned the relevance of this. His background lay in demanding fields of observational science and experiment, his foreground in multinational industrial research planning in his 10 years as research director of Shell Chemicals. All the indications are that however strange the advice proffered by Lord Rothschild's think-tank it was genuinely independent. The change can only mean a reduction in the role of science in government, especially as the post of Chief Scientific Adviser has also lost status recently. Does the government really want informed, independent pacing of its

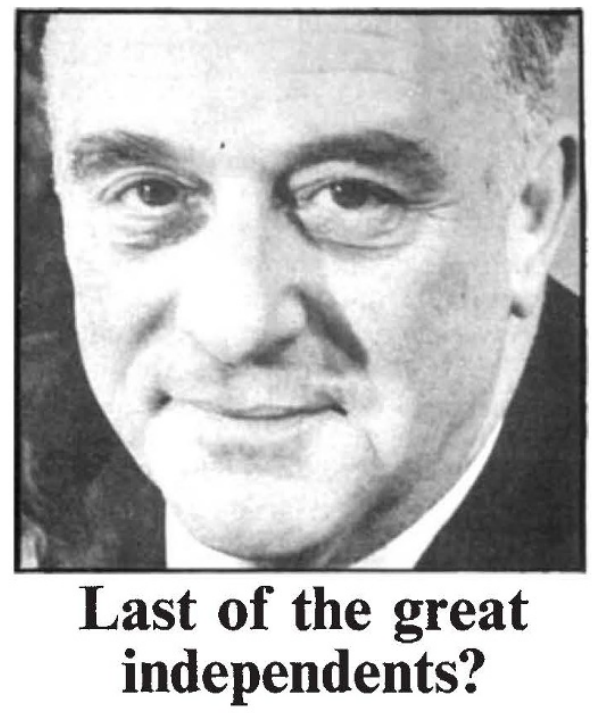

performance 'within the system'?

Two years ago Lord Rothschild assessed the importance of the CPRS as follows: "Regional policy is the most intractable problem we have been faced with, but the most difficult and important is this analysis of the government's strategy". Perhaps today he would reassess the relative intractability of the subjects under study.

In general the subjects which the Cabinet has referred to the CPRS are confidential - as are the recommendations made. But it is known that apart from government research funding, inflation and energy it has studied Concorde, the British computer industry, the Post Office giro, whether there is an optimum population level for the nation, multinational companies and the bane of all governments, regional policy.

The think-tank has, under various circumstances, published three of its 'thinks'. There was (and is) the redistribution of government research funds which threw Lord Rothschild himself into public prominence and is still somewhat controversial. He has continued to maintain that before the White Paper's adoption "the organisation of government science was wrong" but has subsequently admitted "the only real regret $\mathrm{I}$ have is that I did not explain the customer/contractor principle. I didn't explain it because I thought it self evident. But it evidently was not so." If he had, this would have made the report three times as long but perhaps "some of the scientists would have been less hostile".

The study on population has also been published and most recently the thinktank's long gestated views on energy were drilled out of the government machine by the Secretary of State for Energy, Mr Eric Varley. Nonetheless the think-tank published first and its emphatic reliance on saving energy rather than flirting with alternative energy sources was firmly lodged in the Department of Energy's paper which appeared a fortnight later. Particularly appealing features of the CPRS's Energy Conservation were the emphasis on an industrialists' 'annual energy audit' the possibility of saving substantially on electric light bulbs and the criticisms of large, fast uneconomic private cars. It would be a fitting memorial to Lord Rothschild's quirky reign in Whitehall if he could get public acceptance of a slow, small economical battery-driven urban runabout.

In the meantime, it seems that the CPRS is being downgraded with Rothschild's departure. Mr Wilson has already appointed a parallel unit of about eight advisers, currently untitled, but effectively an economics think-tank within No. 10 Downing Street itself headed by $\mathrm{Dr}$ Bernard Donoghue. 